\title{
The Impact of Distributed Leadership Behaviors of School Principals on the Organizational Commitment of Teachers
}

\author{
Öznur Ataş Akdemir ${ }^{1, *}$, Ahmet Ayik ${ }^{2}$ \\ ${ }^{1}$ Faculty of Education, Ağrı İbrahim Çeçen University, Turkey \\ ${ }^{2}$ Kazım Karabekir Faculty of Education, Atatürk University, Turkey
}

Copyright $\odot 2017$ by authors, all rights reserved. Authors agree that this article remains permanently open access under the terms of the Creative Commons Attribution License 4.0 International License

\begin{abstract}
This study aims to investigate the effect of school principals' distributed leadership behaviors on teachers' organizational commitment. For this purpose, correlational survey model has been used in this study. The study group consists of 772 teachers working at secondary schools of Erzurum. The data of the study has been collected by using Distributed Leadership Inventory which was developed by Hulpia, Devos and Rosseel (2009a) and adapted to Turkish by Baloğlu (2012), and Organizational Commitment Scale for Teachers which was developed by Üstüner (2009). The data has been analyzed with SPSS programme. Some descriptive statistics such as frequencies, percentages, arithmetic mean and standard deviation have been used. Besides, Pearson Moment Correlation has been used in order to determine the relationships among the variables; and multiple linear regression analysis has been used to investigate predictive power of distributed leadership. According to the findings of the study, it is determined that teachers' perceptions towards school principals' distributed leadership behaviors and organizational commitment are at moderate level. The findings of the study have revealed that there is a positive and significant relationship between school principals' distributed leadership behaviors and teachers' organizational commitment. Besides, school principals' distributed leadership behaviors significantly predict teachers' organizational commitment.
\end{abstract}

Keywords Distributed Leadership, Organizational Commitment, School Principals, Teachers

\section{Introduction}

In our age, structure of educational organizations has become so much complex over the years, and it is impossible that only one person can deal with all the problems and make a decision by himself/herself in such a complex structure. Therefore, perception of one leader has been put aside in schools. Instead, perception of distributed leadership in which duties and responsibilities are shared has gained currency (Uslu and Beycioğlu, 2013). One of the supporters of the opinion that one leader cannot succeed in dealing with the things in schools because of their complex structures, Jacobs (2010) has asserted that distributed leadership in school requires cooperation, emphasizing that it is necessary to benefit from the skills of principals, teachers, and other personnel.

Distributed perspective on school leadership and management has attracted the attention of politicians, practitioners, and researchers across the world in recent years (Harris, 2013; Spillane and Healey, 2010). Distributed leadership, described as a system created by a lot of components coming together in an organization by Spillane, Halverson, and Diamond (2001), is defined as the distribution of leadership in educational organizations instead of an individual's taking the responsibility for leadership. Therefore, tasks and responsibilities in an organization are shared, and decision making becomes collaborative. However, everyone in the group doesn't have to be leader from a distributed perspective (Spillane and Healey, 2010). In other words, taking the lead depends on a voluntary basis. In this case, leadership is influenced by the interaction between the individuals in the organization.

Supporters of distributed leadership attribute leadership process to the whole group, not an individual. According to them, leadership is a dance which is performed by the members of the group moving to the beat, so duties are carried out in harmony. According to another research, distributed leadership is not an individual's being leader but leadership's distribution among all the members of a group. In this opinion, leadership is not individual, but collaborative (Wilmore, 2007).

Distributed leadership perspective points out that school 
management requires multiple leaders and that responsibility should be divided or shared (Gronn, 2003; Grubb, Flessa, Tredway, and Stern, 2003). Also, Çelik (2013) has stated that a distributed leadership which coincides with the structure of school brings about sharing as well as accountability. This kind of leadership provides that responsibilities and authority in educational organizations are given to other members of the organization. As a result of this distribution, the principle of accountability is also shared by all the members of the organization.

Distributed leadership plays an important role on the spread of accountability as well as it appears as a component helpful in the implementation of democracy at schools. To create a democratic environment at schools becomes possible when teachers participate in the process of decision-making and share the leadership in school management (Çelik, 2013; Harris, 2012; Mayrowetz, 2008).

School principals' distributed leadership behaviours also affect teachers' perceptions of organizational commitment. Organizational commitment is that employees want to stay in organization without financial worries, identifying themselves with the objectives and values of the organization (Gaertner and Nollen, 1989). Organizational commitment is also defined as a powerful precursor of teachers' effectiveness (Dee, Henkin and Singleton, 2006). Teachers whose commitment levels are high show more professional efforts and cooperation, and they are less likely to resign or withdraw from their organizations (Singh and Billingsley, 1998). Firestone and Pennell (1993) have suggested that organizational commitment, an important source of motivation for professionalization and for getting over the difficulties, is an important precursor of teachers' working performance. Researches have shown that there is a positive relationship between the employees' organizational commitment and organizational leadership practices (Meyer and Allen, 1997; Nguni, Sleegers, and Denessen, 2006).

The concept of organizational commitment, one of basic subjects of educational administration, is also defined as attitude of being loyal to organization, an ongoing process of individuals' participation in organizational decisions, and a condition which provides welfare and success and limits the freedom in an organization (Javadi and Yavarian, 2011). It is undeniable that organizational commitment affects distributive leadership. For instance, that teachers have high levels of organizational commitment at a school will increase their participation in the distributed leadership practices.

Teachers who have high levels of commitment strive to solve the problems instead of causing them in school organization. For this reason, ensuring teachers commitment to school organization is important for organization to continue its existence and to reach its objectives (Mikkelsen and Einarsen, 2001). Teachers' cooperation wishing to make an effort to accomplish the objectives of the school is a result of their organizational commitment. Teachers' working as a team in accordance with the purpose of accomplishing a common objective coincides with the concept of distributed leadership (Malik and Naaem, 2011).

Teachers' organizational commitment has been studied in a lot of researches and it has been found that teachers' organizational commitment develops through some features of organizational environments, such as school leadership (Meyer and Allen 1997; Nguni, Sleegers, and Denessen, 2006; Ross and Gray, 2006). Researches have shown that supportive school principals have positive effect on teachers' organizational commitment (Nguni, Sleegers, and Denessen, 2006; Park, 2005). When principals give teachers feedback, encourage and inform them, and set goals for them, teachers show much more commitment to their schools (Nguni, Sleegers and Denessen, 2006; Park, 2005; Tsui and Cheng, 1999). Somech (2005) has pointed out that there is a positive relationship between directive leadership, defined as monitoring and supervising teachers, and organizational commitment. It has been determined that there is a positive relationship between teachers' participation in the process of decision-making and their organizational commitment (Diosdado, 2008; Kushman, 1992). According to Firestone and Pennel (1993), the effect of collaborative decision-making on organizational commitment may change significantly depending on some conditions. These conditions are introduced as the areas teachers are effective, the levels of management's openness to these effects, teachers' normative levels of acceptance about such opportunities, the organization of participation process, whether teachers are really effective or not, and the results of decision-making process.

Teachers' taking the role of leadership at schools in which distributed leadership is implemented at a high level is thanks to their commitment to their schools (Hulpia and Devos, 2010). Researchers have suggested that sustainable development of school need to be supported by leadership that is distributed among partners, in other words, among principal, teachers, and other school personnel (Barth, 2001; Fullan, 2001; Harris, 2003; Marks and Printy, 2003; Stoll and Fink, 1996). Implementation of distributed leadership at schools contributes to the emergence of organizational commitment which means that teachers feel sincere attachment and commitment to their schools (Ağıroğlu Bakır, 2013).

Distributed leadership has recently developed new perspectives to lead studies on educational leadership. Studies on distributed leadership have made significant contributions to issues such as school effectiveness (Muijs, 2009), student success (Chang, 2011; Chen, 2007; Cochran, 2007; Heck and Hallinger, 2009; Leithwood and Mascall, 2008), organizational change (Harris, Leithwood, Day, Sammons, and Hopkins, 2007; Sloan, 2013), democracy at schools (Harris, Hargreaves, and Fink, 2008; Woods, 2004; Woods and Gronn, 2009) and participation in 
decision-making process (Mayrowetz, 2008; Park and Datnow, 2009). However, this approach has constraints in terms of research and implementation (Çelik, 2013). Therefore, we believe that this study on distributed leadership and organizational commitment will overcome the deficiencies in both research and implementation areas to a certain degree and play an important role in distributed leadership perspective's being adopted and implemented by principals.

The aim of this study is to examine the effect of principals' distributed leadership behaviors on teachers' organizational commitment. Therefore, it has searched for answers to following questions:

1. What are the levels of teachers' perception of school principals' distributed leadership behaviors?

2. What are levels of teachers' organizational commitment?

3. Is there a significant relation between school principals' distributed leadership behaviors and teachers' organizational commitment?

4. Do school principals' distributed leadership behaviors predict teachers' organizational commitment significantly according to teachers' perceptions?

\section{Method}

\subsection{Research Model}

Correlational survey model has been used in this study which is aimed at examining the effect of school principals' distributed leadership behaviors on teachers' organizational commitment according to the perceptions of the teachers working at secondary schools. In this correlational survey model, school principals' distributed leadership behaviors have been regarded as independent variable, and organizational commitment as dependent variable.

\subsection{Study Group}

The study group consists of 772 teachers working at 40 state-run secondary schools of Erzurum. The data of study has been collected by the researcher going to the schools with the permission of Erzurum Provincial Directorate for National Education, which is in charge of the schools in the scope of study, after official correspondence. 425 (55.1\%) of participants are female, and $347(44.9 \%)$ are male. Of teachers participating in the study, $389(50.4 \%)$ have $1-5$ years of working experience (professional seniority), 179 $(23.2 \%)$ have 6-10 years of working experience, 106 $(13.7 \%)$ have $11-15$ years of working experience, $51(6.6 \%)$ have 16-20 years of working experience, and $47(6.1 \%)$ have 21 and more years of working experience. When educational status of participants is analyzed, it has been seen that 705 participants (91.3) have Bachelor's Degree, and 67 (8.7\%) have Master's Degree.

\subsection{Data Collection}

The data of the study has been collected by using Distributed Leadership Inventory and Organizational Commitment Scale for Teachers.

Distributed Leadership Inventory has been developed by Hulpia, Devos and Rosseel (2009a) with the purpose of determining teachers' perception levels of school principals' distributed leadership behaviors and adapted to Turkish by Baloğlu (2012) in order to collect data in a study. Researcher has got necessary permission from the researcher who adapted the inventory by e-mail before using the scale. The scale consists of 23 items which is rated on 5 points Likert Scale as: strongly disagree (1), disagree (2), neither agree nor disagree (3), agree (4), and strongly agree (5). Distributed Leadership Inventory consists of 3 dimensions, namely team working, support, and supervision. Total internal consistency factor for inventory has been calculated as .96 , and .90 for support, .90 for supervision, and .94 for team working. These rates have shown that internal consistency level of the scale is high and that the scale is reliable.

Organizational Commitment Scale for Teachers has been developed by Üstüner (2009) for the purpose of measuring teachers' perceptions of organizational commitment. Researcher has got necessary permission by e-mail from the researcher who has developed the scale before using the scale. The scale is one-dimensional and consists of 17 items which is rated on 5 points Likert Scale as: never (1), rarely (2), sometimes (3), frequently (4), and always (5). To determine the reliability of the scale for the study, Cronbach's Alpha coefficient of internal consistency has been calculated by the researcher. Coefficient of internal consistency for Organizational Commitment Scale for Teachers has been calculated as .96. This rate has shown that internal consistency level of the scale is high and that the scale is reliable.

\subsection{Analysis of Data}

SPSS 22.0 has been used for analysis of the data. Of descriptive statistics, arithmetic mean, standard deviation, frequency, and percentage have been used in analyzing the data. The data of the study have been analyzed using statistical techniques appropriate for the purpose of the study and normality distribution of the data. Pearson Moment Correlation Analysis has been performed in order to determine the relationships between school principals' distributed leadership behaviors according to teachers' perception and teachers' organizational commitment. Then, it has been checked if the necessary conditions are ensured for regression analysis. At first, the coefficients of skewness and kurtosis of the data have been examined, and it has been determined that the data has distributed normally. Coefficients of Mahalanobis distance values 
have been examined in order to determine the multiple normality of the data and it has been found that it has multiple normality. In analysis performed for determining if there is a multicollinearity problem between independent variables, it has been seen that VIF values change between 2.46 and 3.42 and are smaller than 10; and CI values change between 8.37-15.20 and are smaller than 30 while their tolerance values are quite high; and these results have shown that there is no multicollinearity problem (Tabachnick and Fidell, 2001). Finally, Durbin Watson values have been observed in order to examine autocorrelation between the variables. Durbin Watson coefficient has been observed as 1.73 and determined to be among 1.5-2.5 which are accepted as limit values (Field, 2005). After prior conditions have been ensured, multiple linear regression analysis has been performed in order to determine the regression level of school principals' distributed leadership behaviors on teachers' organizational commitment.

\section{Findings}

To what extent are teachers' perception related to school principals' distributed leadership behaviors? is the first subproblem of the research. Table 1 presents the findings of the school principals' distributed leadership behaviors and its sub-dimensions according to the perceptions of the teachers who participated in that research.

Table 1. Arithmetic Mean and Standard Deviation of the School Principals' Distributed Leadership Behaviors and Its Sub-dimensions according to the Perceptions of the Teachers

\begin{tabular}{|c|c|c|c|}
\hline Dimensions & $\mathrm{n}$ & $\bar{X}$ & $\mathrm{Sd}$ \\
\hline Support & 772 & 3.36 & .97 \\
\hline Supervision & 772 & 3.21 & 1.00 \\
\hline Team working & 772 & 3.19 & 1.03 \\
\hline Total Distributed Leadership & 772 & 3.25 & .91 \\
\hline
\end{tabular}

When Table 1 is analyzed, it is determined that teachers' perceptions towards school principals' distributed leadership behaviors are at the moderate level $(\bar{X}=3.25)$. The findings, as shown in Table 1, show that teachers' perceptions towards school principals' distributed leadership behaviors are at different levels. According to these findings, while the support dimension of school principals' distributed leadership behaviors is perceived by the teachers at the highest level $(\bar{X}=3.36)$, the team working dimension is perceived at the lowest level. ( $\overline{\boldsymbol{X}}=$ 3.19)

What is the teachers' organizational commitment level? is the second subproblem of the research.The findings related to the organizational commitment level of the teachers who participated in the research are given in Table 2 .
Table 2. Arithmetic Mean and Standard Deviation of Organizational Commitment Level of the Teachers

\begin{tabular}{|c|c|c|c|}
\hline & $\mathrm{n}$ & $\bar{X}$ & $\mathrm{Sd}$ \\
\hline Organizational commitment & 772 & 3.09 & .96 \\
\hline
\end{tabular}

When Table 2 is analyzed, it is seen that organizational commitment level of the teachers who participated in the research is at the moderate level $(\bar{X}=3.09)$.

Is there a significant relationship between school principals' distributed leadership behaviors and teachers' organizational commitment? is the third subproblem of the research. In this aspect, the findings related to the relationship between school principals' distributed leadership behaviors and teachers' organizational commitment are given in Table 3.

Table 3. Pearson Moment Correlation Analysis Results of the Relationship between School Principals' Distributed Leadership Behaviors and Teachers' Organizational Commitment

\begin{tabular}{|c|c|c|c|c|c|}
\hline & 1 & 2 & 3 & 4 & 5 \\
\hline 1.Support & - & & & & \\
\hline 2.Supervision & $.76^{* *}$ & - & & & \\
\hline 3. Team working & $.66^{* *}$ & $.78^{* *}$ & - & & \\
\hline 4. Total Distributed Leadership & $.87 * *$ & $.91 * *$ & $.93 * *$ & - & \\
\hline 5. Organizational Commitment & $.48^{* *}$ & $.60 * *$ & $.63 * *$ & $.64 * *$ & - \\
\hline$* \mathrm{p}<.05, * * \mathrm{p}<.01$
\end{tabular}

As can be seen in Table 3, a positive and significant relationship between support that is one of the sub-dimensions of the school principals' distributed leadership behaviors and organizational commitment $(\mathrm{r}=.48, \mathrm{p}<.01)$ is determined. With regard to that finding, the more school principals' supporting behaviors increase, the more teachers' organizational commitments increase.

The positive and significant relationship between supervision that is one of the sub-dimensions of the school principals' distributed leadership behaviors and organizational commitment $(r=.60, \mathrm{p}<.01)$ is determined. With regard to that finding, the more school principals' supervision behaviors increase, the more teachers' organizational commitments increase.

The positive and significant relationship between team working that is one of the sub-dimensions of the school principals' distributed leadership behaviors and organizational commitment $(\mathrm{r}=.63, \mathrm{p}<.01)$ is determined. With regard to that finding, the more school principals' team working behaviors increase, the more teachers' organizational commitments increase.

There is a positive and significant relationship between the school principals' distributed leadership behaviors and organizational commitment $(\mathrm{r}=.64, \mathrm{p}<.01)$. According to this finding, while the school principles' distributed leadership behaviors increase, the teachers' organizational commitments also increase. 
Table 4. Multivariate Linear Regression Analysis Matrix of Prediction of Teachers' Organizational Commitment

\begin{tabular}{|c|c|c|c|c|c|c|c|}
\hline Variable & $\mathrm{B}$ & $\mathrm{Sh}$ & $\beta$ & $\mathrm{t}$ & $\mathrm{p}$ & Zero-order $\mathrm{r}$ & Partial $\mathrm{r}$ \\
\hline Constant & 1.020 & .099 & - & 10.267 & .000 & - & - \\
\hline Support & .001 & .042 & .001 & .023 & .982 & .482 & .001 \\
\hline Supervision & .266 & .049 & .278 & 5.463 & $.000^{*}$ & .596 & .193 \\
\hline Team working & .379 & .041 & .409 & 9.285 & $.000^{*}$ & .625 & .318 \\
\hline
\end{tabular}

$F=187.046 ;{ }^{*} p<.05 ; R=.65 ; R^{2}=.42$

Do the school principals' distributed leadership behaviors predict the teachers' organizational commitment according to teachers' perception? is the fourth subproblem of the research. Besides, Pearson Moment Correlation has been used in order to determine the relationships among the variables; and multivariate linear regression analysis has been used to investigate predictive power of distributed leadership. In order to predict the teachers' organizational commitments, multivariate linear regression analysis between the school principals' distributed leadership behaviors and teachers' organizational commitment has been used. Results of the multivariate linear regression analysis related to the prediction of teachers' organizational commitments are given in Table 4.

When Table 4 is analyzed, it shows that as a result of multiple linear regression analysis,there is a significant relationship $\left(\mathrm{R}=.65, \mathrm{R}^{2}=.42\right)$ between the variables namely support, supervision and team working which are sub-dimensions of the school principals' distributed leadership behaviors and teachers' organizational commitment. ( $F=187.046, p<.01)$. According to this result, school principals' behaviors namely support, supervision and team working explains nearly $42 \%$ of total variance of teachers' organizational commitment. According to the standardized regression index, the importance order of predictor variables on organizational commitment is; team working $(\beta=.409)$, supervision $(\beta=.278)$ and support $(\beta=.001)$. When the significance test of regression index is taken into consideration, it is seen that only two predictor variables can be categorized as significant predictor on organizational commitment. These significant predictor variables are supervision $(p<.01)$ and team working $(p$ $<.01)$. When the relationship between organizational commitment and predictor variables are analyzed, these results are found: organizational commitment and support $(\mathrm{r}=.482)$ [when other variables controlled $(\mathrm{r}=.001)$ ], organizational commitment and supervision $(\mathrm{r}=.596)$ [when other variables controlled ( $\mathrm{r}=.193)$ ], organizational commitment and team working ( $\mathrm{r}=.625)$, [when other variables controlled $(\mathrm{r}=.318)]$.

\section{Results, Discussion and Conclusions}

Depending on the perceptions of the teachers who participated in the research the school principals' distributed leadership behaviors are found at moderate level. Besides, it is determined that according to the teachers' perceptions school principals mostly show supporting behaviour that is one of the sub-dimensions of distributed leadership. On the other hand they exhibit behaviors related to the team working less frequently. That finding shows that school principals support the teachers in terms of leadership. That teachers take the lead in the fields in which they are proficient makes a contribution to create a positive organization atmosphere and develop schools. Hammersley-Fletcher (2005) stated that support of school principals plays an important role in the development of teacher leaders and both school principals and colleague's support contributes to creating a collaborative school culture. Besides it is remarkable that school principals exhibit behaviors related to the teamwork less frequently. That the school principals do not internalize a collaborative approach and can result from the fact that the collaborative school culture isn't developed or the fact that the school principals do not trust in the teachers. It can be stated that working as a team in the school improve the collaboration between teachers and it contributes to organizational commitment. In this context, that the school principals show required attention to the teamwork is crucial in terms of school's development. The findings of the studies on distributed leadership which is one of the contemporary leadership approaches show similarities between the results of this research. (Ağırdaş, 2014; Ağıroğlu Bakır, 2013; Baloğlu, 2012; Byfield, 2007; Cochran, 2007; Eggen, 2010; Grant 2011; Heck ve Hallinger, 2009; Hulpia, Devos ve Rosseel 2009b; Laughlin, 2011; Lizotte, 2013; Rabindarang, Bing ve Yin, 2014; Uslu ve Beycioğlu, 2013; Y1lmaz, 2013; Y1lmaz ve Turan, 2015).

It is found that the teachers' organizational commitments are at moderate level. That the teachers' organizational commitments are strong can influence organizational outputs in a positive way and it helps overcome the problems related to the organization. Besides, it can be explained as the teachers do not have the idea of quitting the job and they make the required effort to achieve school's goal. Güney (2011) stated that employees whose level of organizational commitments are high effort excessively in order that their organization can reach success. It is seen that the studies that were done on that topic support that findings. (Ay1k and Ataş, 2014; Kul and Güçlü, 2010; Uslu and Beycioğlu, 2013). Through their work that is related to teachers 'organizational 
commitment and school culture Ayık and Ataş (2014) came to the conclusion that teachers' affective commitments are stronger than their continuance commitment and their normative commitment. Kul and Güçlü (2010) revealed that teachers demonstrate lower level of organizational commitment in the compliance sub-dimension, moderate level of organizational commitment in the identification sub-dimension and higher level of organizational commitment in the internalization sub-dimension. Uslu and Beycioğlu (2013) detected that while teachers' organizational commitment, continuance commitment and normative commitment are at moderate level, their affective commitment is at higher level.

It is determined that there is a positive and significant relationship between school principals' distributed leadership behaviors and teachers' organizational commitment. According to this finding, when the school principals exhibit leadership behaviors more frequently, teachers' organizational commitment also increases. At the end of this literature review, it is seen that the studies on this topic support this finding. (Ağıroğlu Bakır, 2013; Uslu and Beycioğlu, 2013). Ağıroğlu Bakır (2013) found a positive and significant relationship between the public school teachers' distributed leadership perceptions and their organizational commitment. Uslu and Beycioğlu (2013) determined that there is a moderate positive relationship between school principals' distributed leadership roles and teachers' organizational commitment.

It is found a positive and significant relationship between sub-dimensions of distributed leadership behaviors namely support, supervision, and team working. According to this finding, the more school principals' team working, supervision, and support behaviors increase, the more teachers' organizational commitments increase.

Team working and supervision sub-dimensions of distributed leadership behaviors influence teachers' organizational commitment in a positive and significant way. According to literature, prior studies on this topic support this finding (Hulpia, et al., 2009b; Hulpia and Devos, 2010; Hulpia, Devos and Keer, 2011). Hulpia et al. (2009b) found that distributed leadership has a strong influence on the teachers' organizational commitment in their studies on distributed leadership and teachers and teacher leaders' job satisfaction and organizational commitment in secondary schools. Hulpia and Devos (2010) determined that the differences in distributed leadership variables such as distribution of leadership functions and quality, social interaction, cooperation of leadership team and participative decision-making influence organizational commitment in their qualitative research. Hulpia, Devos and Keer (2011) found that quality of the supportive leadership, cooperation within the leadership team, participative decision-making are the sub-dimensions that determine the teachers' organizational commitment in their study that examines the relationship between school leadership and teachers' organizational commitment from the point of view a distributed leadership perspective.

Based on the research the following recommendations are offered for related future research and applications.

- At the end of the research, it is seen that school principals' team working behaviors are not at required level. Teamwork in the schools has a positive impact on developing cooperation within colleagues, creating positive school climate and getting positive organizational outputs. In this aspect, in order to build teamwork culture and to make it more effective, school principals can hold meetings that include different out-of-school social activities. Additionally, they can assign duties to groups rather than individuals which makes the teamwork possible, while they are distributing the duties.

- A positive and significant relationship between school principals' distributed leadership behaviors and teachers' organizational commitments is found. Therefore, raising the awareness of school principals related to distributed organizational behaviors and educating them about this topic can contribute to improving teachers' organizational commitment.

- At the end of the research, it is seen that distributed leadership has a positive impact on teachers' organizational commitments. Making applications of distributed leadership widespread in schools makes significant contribution to improving and promoting this variable. Holding seminars, meetings, in-service training courses on that topic can contribute to developing distributed leadership behaviors.

- In view of the fact that there is no adequate studies about distributed leadership, designing application-oriented projects, doing studies on this topic can reveal the practicality of the distributed leadership in the school and it can contribute to developing new structure in Turkish education.

- In the present study, school principals' distributed leadership behaviors and teachers' organizational commitments are examined by taking into account teachers' perspective. For the further studies, students who are the other shareholders of the schools, officials in the schools, school principals, and inspectors can be asked for opinion and the findings can be compared with the variables of this research to reach more detailed results.

\section{Notes}

Note 1. This paper is based on the doctoral dissertation prepared by Öznur Ataş Akdemir under supervision of Dr. Ahmet Ayık. 


\section{REFERENCES}

[1] Ağırdaş, Y. (2014). Resmi liselerde dağıtımcı liderlik ile iş doyumu arasındaki ilişskinin öğretmen görüşlerine dayalı olarak incelenmesi (Çorum örneği). Yayımlanmamış yüksek lisans tezi. Okan Üniversitesi Sosyal Bilimler Enstitüsü, İstanbul.

[2] Ağıroğlu Bakır, A. (2013). Öğretmenlerin paylaşılan liderlik ve örgütsel bağlılık algıları arasındaki ilişskinin analizi. Yayımlanmamış doktora tezi. İnönü Üniversitesi Eğitim Bilimleri Enstitüsü, Malatya.

[3] Ayık, A., \& Ataş, Ö. (2014). An analysis of the relationship between high school teachers' organizational commitment levels and perceptions of school culture. Mevlana International Journal of Education, 4(3), 69-82.

[4] Baloğlu, N. (2012). Değerler temelli liderlik ile dağıtımcı liderlik arasındaki ilişkiler: Okul müdürünün davranışını değerlendirmeye dönük nedensel bir araştırma. Kuram ve Uygulamada Eğitim Bilimleri, 12(2), 1367-1378.

[5] Barth, R. (2001). Teacher leader. Phi Delta Kappan, 82(6), 443-449.

[6] Byfield, F. C. (2007). Distributive leadership: Perceptions of elementary principals and teacher leaders on sharing leadership responsibilities to support student achievement. Unpublished doctoral dissertation. University of La Verne, USA.

[7] Chang, I. (2011). A study of the relationships between distributed leadership, teacher academic optimism and student achievement in Taiwanese elementary schools. School Leadership and Management, 31(5), 491-515.

[8] Chen, Y. (2007). Principals' distributed leadership behaviors and their impact on student achievement in selected elementary schools in Texas. Unpublished doctoral dissertation. Texas A\&M University, USA.

[9] Cochran, M. (2007). Distributive leadership: Perceptions of classroom teachers and teacher leaders on sharing leadership responsibilities to support student achievement. Unpublished doctoral dissertation. University of La Verne, California.

[10] Çelik, V. (2013). Eğitimsel liderlik. Ankara: Pegem Akademi.

[11] Dee, J. R., Henkin, A. B., \& Singleton, C. A. (2006). Organizational commitment of teachers in urban schools: Examining the effects of team structures. Urban Education, 41, 603-627.

[12] Diosdado, M. S. M. (2008). Creating better schools through democratic school leadership. International Journal of Leadership in Education, 11, 43-62.

[13] Eggen, D.D. (2010). Principals' perceptions of distributed leadership in an elementary school setting. Unpublished doctoral dissertation. University of Northern Colorado, USA.

[14] Field, A. (2005). Discovering statistics using SPSS. London: Sage Publication.
[15] Firestone, W. A., \& Pennell, J. R. (1993). Teacher commitment, working conditions, and differential incentive policies. Review of Educational Research, 63(4), 489-525.

[16] Fullan, M. (2001). Leading in a culture of change. San Francisco, CA: Josey-Bass.

[17] Gaertner, K. N., \& Nollen, S. D. (1989). Career experiences, perceptions of employment practices, and psychological commitment to the organization. Human Relations, 42(11), 975-991.

[18] Grant, C. P. (2011). The relationship between distributed leadership and principal's leadership effectiveness in North Carolina. Unpublished doctoral dissertation. North Carolina State University at Raleigh, USA.

[19] Gronn, P. (2003). The new work of educational leaders: Changing leadership practice in an era of school reform. London: Paul Chapman.

[20] Grubb, W. N., Flessa, J., Tredway, L., \& Stern, J. (2003, April). "A job too big for one": Multiple principals and other approaches to school leadership. Paper presented at the annual meeting of the American Educational Research Association, Chicago.

[21] Güney, S. (2011). Örgütsel davranış. Ankara: Nobel Yayın Dağıtım.

[22] Hammersley-Fletcher, L. (2005). Distributing leadership in primary schools. Education 3-13: International Journal of Primary, Elementary and Early Years Education, 33(2), 46-50.

[23] Harris, A. (2003). Teacher leadership as distributed leadership: Heresy, fantasy or possibility. School Leadership and Management, 23(3), 313-324.

[24] Harris, A. (2013). Distributed leadership: Friend or foe? Educational Management Administration \& Leadership, 41(5), 545-554.

[25] Harris, A., Hargreaves, A., \& Fink, D. (2008). Distributed leadership: Democracy or delivery?. Journal of Educational Administration, 46(2), 229-240.

[26] Harris, A., Leithwood, K., Day, C., Sammons, P., \& Hopkins, D. (2007). Distributed leadership and organizational change: Reviewing the evidence. Journal of Educational Change, 8, 337-347.

[27] Heck, R. H., \& Hallinger, P. (2009). Assessing the contribution of distributed leadership to school improvement and growth in math achievement. American Educational Research Journal, 46(3), 659-689.

[28] Hulpia, H., \& Devos, G. (2010). How distributed leadership can make a difference in teachers' organizational commitment? A qualitative study. Teaching and Teacher Education, 26, 565-575.

[29] Hulpia, H., Devos, G., \& Keer, H. V. (2011). The relation between school leadership from a distributed perspective and teachers' organizational commitment: Examining the source of the leadership function. Educational Administration Quarterly, 47(5), 728-771.

[30] Hulpia, H., Devos, G., \& Rosseel, Y. (2009a). Development and validation of scores on the distributed leadership inventory. Educational and Psychological Measurement, 
69(6), 1013-1034.

[31] Hulpia, H., Devos, G., \& Rosseel, Y. (2009b). The relationship between the perception of distributed leadership in secondary schools and teachers' and teacher leaders' job satisfaction and organizational commitment. School Effectiveness and School Improvement, 20(3), 291-317.

[32] Jacobs, G. E. (2010). The relationship between distributed leadership as practiced by principals and the organizational commitment of the teachers. Unpublished doctoral dissertation. Georgia Southern University, USA.

[33] Javadi, M. H. M., \& Yavarian, J. (2011). Effect of organizational identity and commitment on organizational citizenship behavior (Case study: Educational department of Isfahan province). Interdisciplinary Journal of Contemporary Research in Business, 3(2), 100-112.

[34] Kul, M., \& Güçlü, M. (2010). Okul yöneticilerinin liderlik stilleri ile beden eğitimi öğretmenlerinin örgütsel bağl1lıkları arasındaki ilişki. Uluslararası İnsan Bilimleri Dergisi, 7(2), 1021-1038

[35] Kushman, J. W. (1992). The organizational dynamics of teacher workplace commitment: A study of urban elementary and middle schools. Educational Administration Quarterly, 28, 5-42.

[36] Laughlin, M. E. (2011). Distributed leadership practice and the AVID site team as a leadership practice community to prepare all students for college readiness and success in a global society: A multiple case study. Unpublished doctoral dissertation. University of California, USA.

[37] Leithwood, K., \& Mascall, B. (2008). Collective leadership effects on student achievement. Educational Administration Quarterly, 44(4), 529-561.

[38] Lizotte, J. O. (2013). A qualitative analysis of distributed leadership and teacher perspective of principal leadership effectiveness. Unpublished doctoral dissertation. North Eastern University, Boston.

[39] Malik, M. E., \& Naeem, B. (2011). Impact of perceived organizational justice on organizational commitment of faculty: Empirical evidence from Pakistan. Interdisciplinary Journal of Research in Business, 1(9), 92-98.

[40] Marks, H. M., \& Printy, S. M. (2003). Principal leadership and school performance: An integration of transformational and instructional leadership. Educational Administration Quarterly, 3, 370-397.

[41] Mayrowetz, D. (2008). Making sense of distributed leadership: Exploring the multiple usages of the concept in the field. Educational Administration Quarterly, 44(3), 424-435.

[42] Meyer, J. P., \& Allen, N. J. (1997). Commitment in the work place: Theory, research and application. Thousand Oaks, CA: Sage Publication.

[43] Mikkelsen, E. G., \& Einarsen, S. (2001). Bullying in Danish work-life: Prevalence and health correlates. European Journal of Work and Organizational Psychology, 10(4), 393-413.

[44] Muijs, R. D. (2009). Distributed leadership and school effectiveness. Leadership in Education: Dissemination
Conference, Tallinn, EE.

[45] Nguni, S., Sleegers, P., \& Denessen, E. (2006). Transformational and transactional leadership effects on teachers' job satisfaction, organizational commitment, and organizational citizenship behavior in primary schools: The Tanzanian case. School Effectiveness and School Improvement, 17(2), 145-177.

[46] Park, I. (2005). Teacher commitment and its effects on student achievement in American high schools. Educational Research and Evaluation, 11(5), 461-485.

[47] Park, V., \& Datnow, A. (2009). Co-constructing distributed leadership: District and school connections in data-driven decision-making. School Leadership and Management, 29(5), 477-494.

[48] Rabindarang, S., Bing, K. W., \& Yin, K. Y. (2014). The influence of distributed leadership on job stress in technical and vocational education. International Journal of Academic Research in Business and Social Sciences, 4(1), 490-499.

[49] Ross, J. A., \& Gray, P. (2006). Transformational leadership and teacher commitment to organizational values: The mediating effects of collective teacher efficacy. School Effectiveness and School Improvement, 17, 179-199.

[50] Singh, K., \& Billingsley, B. S. (1998). Professional support and its effects on teachers' commitment. The Journal of Educational Research, 91, 229-239.

[51] Sloan, T. (2013). Distributed leadership and organizational change: Implementation of a teaching performance measure. The New Educator, 9(1), 29-53.

[52] Somech, A. (2005). Directive versus participative leadership: Two complementary approaches to managing school effectiveness. Educational Administration Quarterly, 41, $777-800$.

[53] Spillane, J. P., Halverson, R., \& Diamond, J. B. (2001). Investigating school leadership practice: A distributed perspective. Educational Researcher, 30(3), 23-28.

[54] Spillane, J. P., \& Healey, K. (2010). Conceptualizing school leadership and management from a distributed perspective: An exploration of some study operations and measures. Elementary School Journal, 111(2), 253-281.

[55] Stoll, L., \& Fink, D. (1996). Changing our schools. London: Open University Press.

[56] Tabachnick, B. G., \& Fidell, L. S. (2001). Using multivariate statistics. (4th Edition). MA: Allyn and Bacon Inc.

[57] Tsui, K. T., \& Cheng, Y. C. (1999). School organizational health and teacher commitment: A contingency study with multi-level analysis. Educational Research and Evaluation, 5(3), 249-268

[58] Uslu, B., \& Beycioğlu, K. (2013). İlköğretim okulu öğretmenlerinin örgütsel bağlılıkları ile müdürlerin paylaşılan liderlik rolleri arasındaki ilişki. On Dokuz Mayıs Üniversitesi Eğitim Fakültesi Dergisi, 32(2), 323-345.

[59] Üstüner, M. (2009). Öğretmenler için örgütsel bağl1lık ölçeği: Geçerlik ve güvenirlik çalışması. İnönü Üniversitesi Eğitim Fakültesi Dergisi, 10(1), 1-17.

[60] Wilmore, E. (2007). Teacher leadership: Improving teaching 
and learning from the inside. New York: Corwin Press.

[61] Woods, P. A. (2004). Democratic leadership: Drawing distinctions with distributed leadership. International Journal of Leadership in Education, 7(1), 3-26.

[62] Woods, P.A., \& Gronn, P. (2009). Nurturing democracy the contribution of distributed leadership to a democratic organizational landscape. Educational Management, Administration \& Leadership, 37(4), 430-451.
[63] Y1lmaz, A. İ. (2013). İlköğretim okulu öğretmenlerinin paylaşılan liderlik davranışları. Yayımlanmamış yüksek lisans tezi. Dokuz Eylül Üniversitesi Eğitim Bilimleri Enstitüsü, İzmir.

[64] Yılmaz, D., \& Turan, S. (2015). Dağıtılmış liderliğin okullardaki görünümü: Bir yapısal eşitlik modelleme çalışması. Kuram ve Uygulamada Eğitim Yönetimi, 21(1), 923-126. 